\title{
Activity-Based Costing: Helping Small and Medium-Sized Firms Achieve a Competitive Edge in the Global Marketplace
}

\author{
Mehmet C Kocakulah ${ }^{1 *}$, Abbas Foroughi ${ }^{1}$, Ann Stott ${ }^{2}$ and Lionel Manyoky ${ }^{3}$ \\ ${ }^{1}$ Department of Accounting and Business, University of Southern Indiana, Evansville, USA \\ ${ }^{2}$ School of Accountancy, Ohio University, Athens, Ohio, USA
}

${ }^{3}$ Springleaf Financial Services, Evansville, USA

\begin{abstract}
Since the 1970s, activity-based costing (ABC) has enabled companies to identify the true costs of processes and products and to make sound decisions related to the profitability and expense of the products they produce, as well as the effectiveness of their manufacturing and business processes. This paper explores the advantages of activity-based costing vs. traditional costing systems and presents arguments for the potential benefits to the world's millions of small to medium business (SMEs) from implementing $A B C$. Issues related to the implementation of $A B C$ are discussed. A framework for ABC implementations in SMEs is presented that shows the variables (characteristics of SME and implementation challenges) that can impact the $A B C$ implementation process, and/or ultimately, implementation outcomes.
\end{abstract}

Keywords: Activity-based costing (ABC); $A B C$ implementation; ABC benefits and profitability

\section{Introduction}

Since the 1970s, activity-based costing (ABC) has enabled companies in free markets around the world to identify the true costs of processes and products and make sound decisions related to the profitability and expense of the products they produce, as well as the effectiveness of their manufacturing and business processes. $\mathrm{ABC}$ enables companies to achieve and maintain competitiveness in the global marketplace of the twenty-first century. ABC has been successfully implemented in large firms, and researchers are now finding that $\mathrm{ABC}$ can be the key to creating a competitive edge in small to medium enterprises, which, worldwide, represent close to ninety-seven per cent of all permanent, full-time jobs [1]. This paper focuses on the potential for SMEs to grow in revenue and competitiveness by adopting ABC. The paper begins by describing the importance of SMEs, referred to as "the world's civil society builders" by the European Parliament [2], in free market economies and the crucial importance of supporting their development. ABC is then presented as a means for SMEs to achieve cost savings and transparency in their operations that can help them achieve competitiveness in the global marketplace. A literature review outlines what previous researchers have found during investigations of $\mathrm{ABC}$ implementations in SMEs and presents a framework that shows the impact of SME characteristics and $\mathrm{ABC}$ implementation challenges on the implementation process and outcomes achieved. The paper finishes with conclusions and future research directions.

\section{Literature Review}

\section{SME}

Large, high-profile, multinational firms receive an overwhelmingly greater amount of media attention and name recognition, but, as the following facts indicate, the role of small to medium firms (SMEs) (here defined as those with 500 or less employees) in the USA, as well as in the economies of free-market countries around the world, is significant.

In terms of employment, the USQ has between 25 and 27 million SMEs, employing 120 million people, which accounts for $60-80 \%$ of all jobs [3-5]. In the United States, small businesses have generated $63 \%$ of new jobs between 1993 and 2013 (US Small Business Administration). Worldwide, more than $95 \%$ of enterprises are SMEs, which account for $67 \%$ of employment in the private sector and $52 \%$ of private sector value added [1,6,7]. Between 2002 and 2010, 85\% of total employment occurred in SMEs [8]. SMEs are more innovative than larger companies, and they develop and commercialize the majority of innovative products and services $[9,10]$. The European Parliament has called SMEs "civil society builders" [2].

They provide the potential to close the gap between rich and poor in developing countries, by providing employment to people not employable by larger companies [11-13]. SMEs are the nursery for larger firms of the future, contributing significantly to aggregate savings, technology development, and investment (World Bank). They are incubators for innovation and employment growth, both in the United States and in developing countries [10,14]. SMEs can help developing countries to transition from agrarian-based to manufacturing-based economies and to recover from instabilities created by war $[2,15]$. Entrepreneurs and the SME sector are key drivers of economic development $[10,16]$ and job creation in SMEs requires low capital expenditures, which is important for developing countries $[17,18]$. Another key role of the SME sector is the opportunity it provides to women, both in developed and developing countries, to be important economic players in micro and small enterprise creation and development [2].

The above facts indicate that SMEs, the world's civil society builders, represent a significant segment of commerce worldwide, providing employment to the most people worldwide, fostering

*Corresponding author: Mehmet C Kocakulah, Professor, Department of Accounting and Business, University of Southern Indiana, Evansville, USA, Tel: 812 4641730; E-mail: mkocakul@usi.edu

Received June 22, 2017; Accepted July 12, 2017; Published July 19, 2017

Citation: Kocakulah MC, Foroughi A, Stott A, Manyoky L (2017) Activity-Based Costing: Helping Small and Medium-Sized Firms Achieve a Competitive Edge in the Global Marketplace. J Account Mark 6: 245. doi: 10.4172/2168-9601.1000245

Copyright: $\odot 2017$ Kocakulah MC, et al. This is an open-access article distributed under the terms of the Creative Commons Attribution License, which permits unrestricted use, distribution, and reproduction in any medium, provided the original author and source are credited. 
innovation, attracting talent, stimulating economic growth, serving as suppliers and incubators for larger firms, providing opportunities to fight poverty, and contributing to economic development.

Over the past few years, global competition, volatile markets, and a demanding cost accounting environment have put pressure on SMEs which, in many cases, threatens their success $[19,20]$. Small firms lack access to technology, knowledge about modern accounting techniques, and financial backing, and are sometimes impeded by local and regional laws and regulations [21]. At the same time, as argued by Jennings and Disney [22], and Danosh [23], economic instability and competition over the past few years have actually served as a catalyst for change-increased planning and greater flexibility-that can ultimately benefit SMEs.

With the current explosion in population growth, 600 million jobs are needed in the next 15 years to absorb the growing global workforce, mainly in Asia and Sub-Saharan Africa (World Bank). SMEs can potentially provide employment to these hundreds of millions of people. Given the importance of SMEs in the economic opportunity and wellbeing of so many people worldwide, international organizations like The Edinburgh Group, the World Bank, the European Parliament, United Nation agencies, the Association of Chartered Certified Accountants, the Consortium for Advanced ManagementInternational and many other agencies worldwide, at the international and regional levels, have been searching for ways to support SMEs and help them flourish in the global community. Problems typically encountered by SMEs wishing to enter international markets include the lack of formalized work and quality standards, costs, language and cultural barriers, bureaucratic intricacies, limited management and other employee skills, and traditional, often informal accounting practices [6]. SMEs encountered significantly more difficulties than larger companies in recovering from the 2008 global recession [7]. One of the major issues, both in the recovery as well as moving forward into the future, is the crucial importance of cost cutting. An Economist Intelligence Unit report [24] found that SMEs cut costs as they recovered from the recession, but very few developed a formal costcutting plan. Most continue to use traditional, volume-based costing methods which, as the following section of this paper argues, fall short of determining the actual costs and competitiveness of the products or services a company produces.

\section{Activity-based costing}

From the beginning of the industrial revolution until the second half of the twentieth century, most manufacturers produced large amounts of a small number of products, with most cost stemming from direct costs such as materials and labor. Traditional cost accounting focused on direct materials and direct labor in product cost and only estimated overhead costs, ignoring the increasing role of various types of overhead. As industrial capabilities evolved over the past 75 years, manufacturers were able to produce many types of products, in varying amounts, each producing a different amount of overhead. Sophisticated machinery for producing customizable products to order and information systems added even more overhead. By the 1970s, information and communication technology made it possible to gather and process more accurate information about the activities that go into producing a product. In 1971, George Staubus' book, Activity Costing and Input-Output Accounting introduced the idea of activitybased costing, which identifies the activities required to produce a product and assigns cost to each product based on the cost of the activities required to produce it [25]. The Consortium for Advanced Management - International further refined this new concept and formulated the principles of what is now called activity-based costing (ABC) [26]. In the 1990s, Cooper and Kaplin's [27] Harvard Business Review article called for increased use of activity-based cost accounting to identify the true costs of processes and products, so that companies can make sound decisions related to the profitability and expense of the products they produce. ABC has also been strongly advocated in important articles by Kaplan and Bruns [28], Johnson and Kaplan [29], Drucker [30], Drury [31]; Johnson [32], and Ness and Cucuzza [33].

$\mathrm{ABC}$ was originally conceptualized as an effective costing method for manufacturers, but it has been used by numerous other industries, such as hospitals and related healthcare facilities [34-36], by the US Postal Service [37,38], the restaurant and hotel industry $[39,40]$, the life insurance industry [41], universities [42,43], the accounting profession [44], the banking industry [45], the energy sector [46,47], and the food production industry [48]. Large companies like Chrysler [33] and United Parcel Service (UPS) have also benefited from using ABC, particularly in the area of supply chain management [49]. Mahal and Hossain [50] review a number of articles about ABC.

Activity-based costing (ABC) assists companies in more accurately costing their products. While traditional costing systems rely on a simple measure for the allocation of overhead, activity-based costing relies on cost pools and cost drivers to assign cost in accordance with overhead usage. The most important component of activity-based costing is the cost driver used [51]. Cost drivers are the factors that determine the number of activities that will be consumed by a given product. Examples of cost drivers include machine hours, size, complexity, type, and any other product attribute that can determine its cost. This method is utilized in the allocation of overhead expense in managerial accounting. Although researchers differ on the exact steps in $\mathrm{ABC}$ costing, it basically calls for the following procedures, which are also illustrated in Figure 1.

1. Determine the activities that go into producing each product and the cost drivers for measuring them.

2. Determine the costs associated with each activity.

3. Determine the percentage of time employees spend on these activities for each product - through interviews, observation, or logs.

\section{Calculate activity cost driver rates.}

5. Assign costs to products or customers by dividing these activity costs by the output of each activity.

The main purpose of cost accounting (as opposed to financial accounting) in management is to provide data for managers. Managers can use cost data to make decisions that will ultimately improve the company's financial performance. Many of these decisions relate to which products to advertise, which to expand, and which to discontinue. Other decisions attempt to improve operations, lower cost, or allow more competitive pricing. Because all of these decisions rely heavily on cost accounting data, having accurate data are essential for a company in identifying sources of profit and maximizing potential profitability $[52,53]$.

As product lines have become more complex and markets have become more segmented, companies have developed more products for smaller markets. Sales and profits for these markets are smaller than for the previously massed produced products. This change in the competitive environment has made the necessity for more accurate costing information even stronger [44,54]. 
(a) Traditional product costing system

\section{Stage 1: Overheads assigned to \\ Stage 2: Overheads allocated to products} production departments

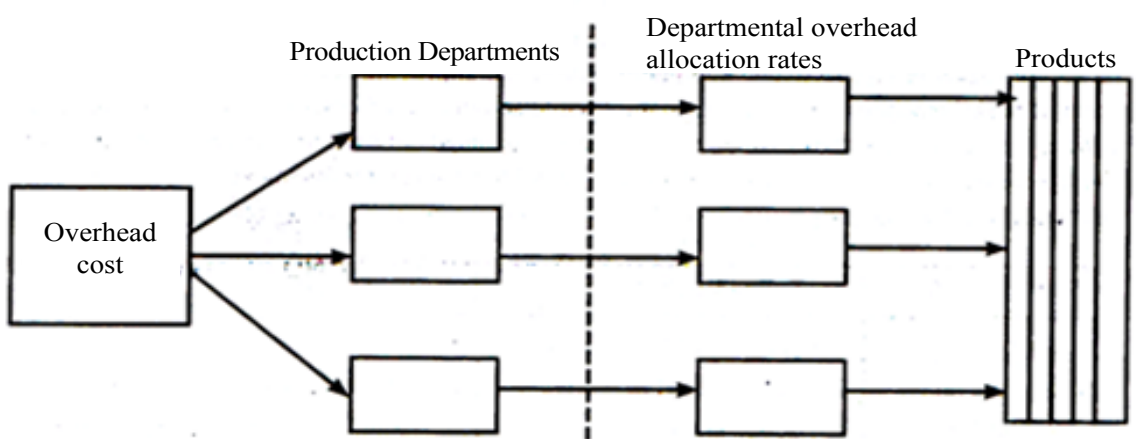

(b) Activity-based product costing system

Stage 1: Overheads assigned to cost centres/ Stage 2: Overheads assigned to products cost pools using cost driver rates

Activity cost driver rates Products

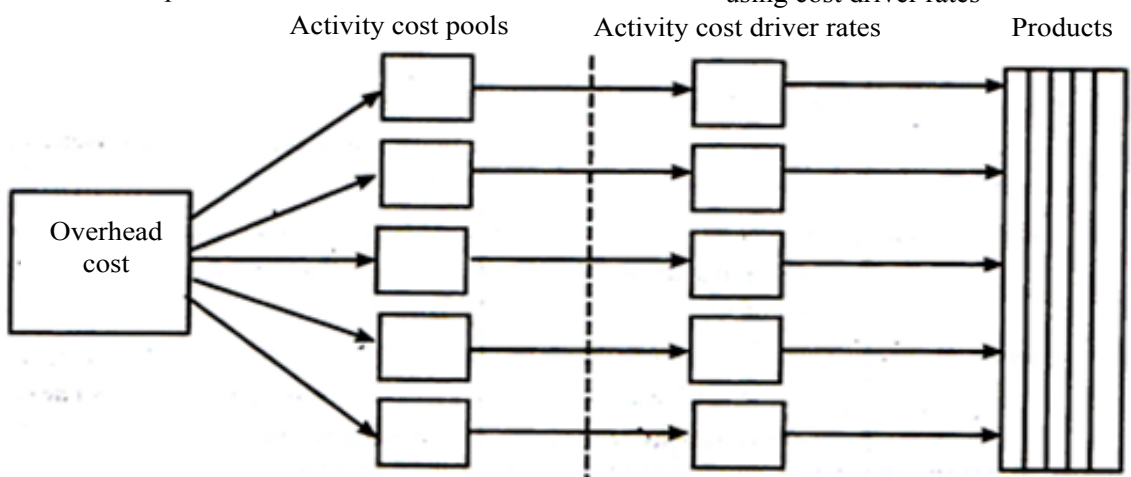

Exhibit 4.6: Comparison of Traditional and Activity-Based Costing Systems

Source: J. Innes and F. Mitchell, Activity-Based Costing: A Revies with Case Studies. 1990, CIMA,U.K.

Figure 1: Comparison of traditional and activity based costing systems

Activity-based costing does a better job of allocating overhead expense because it does not group costs that are spread out across many different activities [55]. Critics of traditional cost accounting systems argue that overhead expenses are being allocated incorrectly, leading to poor management decisions regarding product continuation and pricing. In situations where a competitive bid or cost-plus pricing is required, the actual cost of the product is essential for pricing of a product or service. Decisions based on inaccurate cost data can have a direct impact on the profitability of the company in these situations $[52,56]$.

When indirect cost is a large portion of the overall cost of the product, activity-based costing is superior to traditional costing in providing data for proper pricing decisions $[57,58]$. In past decades, direct labor has been approximately $25-50 \%$ of the total cost of a product, but since the 1960s, it has fallen dramatically. The dominant product cost is now indirect cost [54].

Traditional costing systems tend to use a single rate multiplied by a single factor to determine the overhead allocation for a product, service, or project. This can lead to inaccurate costing, specifically when the incurrence of overhead cost is not proportional to that factor. In a situation where an employee sets up a machine and lets it run while doing other work, using direct labor as the factor for allocating overhead would lead to inaccurate costing. The machine hours, which are typically overhead intensive, are basically ignored, while other activities, assembly for example, are charged high amounts of overhead while using very few resources apart from direct labor. Using a single rate for allocating overhead based on one factor will misallocate overhead because the different operations within a single shop vary widely. Overhead-intensive projects, in particular, tend to be underpriced [53].

Traditional cost systems have been criticized for over-costing simple products that are produced in large batches as well as products that rely on high usage of the allocation base, but lower usage of other significant factors such as machine hours [52]. Standard costing systems also tend to show the cost of special or custom products as being lower than they actually [51]. Inaccurate costing can create losses because difficult work will tend to be under-priced. The costing system may not account for special characteristics or special expertise. As these difficult, complex projects are under-bid, the company will win bids for increasingly unprofitable work. At the same time, simpler projects will be over-priced and subsequently, less of these more profitable projects will be sought and won by the company. This phenomenon can be concealed by inaccurate or insufficient costing systems, leading to erosion of profit margins and causing damage to the company's financial viability [53]. When special/difficult projects are priced 
correctly, there are fewer orders for them, and more orders for standard products. Because special projects require much more support from office staff, a small reduction in the percentage of special orders versus the percentage of standard orders can have a significant impact on the staff resources required for the same level of order activity [51].

Another issue facing companies is how to deal with idle capacity in product costing. Traditional costing systems tend to distribute the cost of idle capacity across products manufactured, essentially concealing its true cost and artificially inflating product cost. Activity-based costing systems do a better job of separating the cost of idle capacity from the true cost of the manufactured products. Including excess capacity in product cost raises the perceived cost of those products without adding value to them. This increase in costs can influence managers to want to raise the prices of these products to increase profitability. This price increase, in the absence of any product improvement or enhancement, can lower sales, causing an increase in idle capacity. As this new idle capacity is reallocated to even fewer products than before, upward pressure on pricing will continue, driving down sales further. This "death spiral" can be avoided by removing the cost of idle capacity from product costs. To avoid this entirely, some costing systems will only allocate overhead expense to products in proportion to the amount of utilized capacity-excluding idle capacity from product cost. Typical costing system users do not feel that their system sufficiently shows the cost of idle time, but users of activity-based costing systems have indicated that they feel that their systems do a much better job [52].

When excluding idle capacity cost from product cost in internal cost accounting, the overall cost stays the same, but the product cost is more accurately represented. This provides a clearer picture of what is making money and what is costing money. Idle capacity as an expense directly impacting the bottom line also draws attention to its cost to the company. This could motivate managers to actively pursue opportunities to utilize excess capacity in order to minimize this cost. When it is distributed among the manufactured products, it is much less obvious and consequently, must less urgent.

Aside from showing the cost of products, a cost accounting system can highlight or conceal possible process and product improvements. Traditional cost accounting systems do not provide a basis from which management can improve [55]. Costing systems that merely show the cost do not show where excess costs may have been incurred. Managers may either conclude that everything is fine, or they may want to make improvements, but feel that they lack the information necessary to make the needed improvements. Managers who feel that their cost systems accurately compute the product cost also feel that these same systems help them reduce costs, measure performance, and enhance revenue [52].

Decisions to outsource can be highly influenced by this faulty thinking. Eventually, operations are increasingly outsourced; margins become thin while production facilities become idle, thus allocating even more overhead cost to the remaining manufactured products. Survival in this situation is very difficult for a company [53]. Activitybased costing works the same way management thinks so that improvements can be made using the costing data produced [55]. $\mathrm{ABC}$ was designed to facilitate more accurate information regarding production processes, costs, and product support activities so that managers are better equipped to make improvements that ultimately increase the profitability of the company.

Decisions regarding product design, product mix, marketing, and product price all can be better analyzed through accurate product costing data. In other words, the whole point of activity-based costing is to provide management a way to drive continual improvement and ultimately enhance company profitability [54]. ABC can help identify important cost-and-profit enhancement opportunities through the repricing of unprofitable customer relationships, process improvements on the shop floor, lower-cost product designs, and rationalized product variety [59].

Without overhead, product costing would be simple: Direct labor and direct materials can be traced directly to products. Overhead is much more difficult to assign correctly and can be a significant portion of product cost. Cost accounting systems (variable, traditional, or activity based) should not be viewed as good or bad, but rather should be chosen based on the appropriateness for the company and the data required [52]. Traditional costing systems are most appropriate when a company or a shop only makes a single product [51]. Generally, using a mix of standard costing and $\mathrm{ABC}$ will help most companies. Some companies use standard cost systems to allocate direct labor and direct materials and activity-based costing to allocate overhead. Other companies use a standard cost system for financial accounting and activity-based costing for internal accounting. Combining the systems can allow companies to retain the advantages of both systemssuperior control for standard costing and superior overhead allocation for activity-based costing [57].

Numerous researchers have outlined internal factors a company should look at closely in determining if it would benefit from implementing $\mathrm{ABC}$. The more of the following factors that exist in the company, the more beneficial it would be to implement $\mathrm{ABC}[58,60,61]$.

1. Direct labor operations have been replaced with automated equipment since the costing system was lastly revised, but overhead is still applied to cost objects based on labor hours.

2. Indirect costs are becoming a much larger percentage of total costs.

3. Only one or a few overhead application rates are in use in the company.

4. The organization finds that one end of its product line is very competitive, while the other is not; but does not understand why.

5. Operations or machinery are used that do not require the same number of operators.

6. Many operations are set up, started, and then run with little or no human intervention.

7. Accounting personnel do not set a priority on determining how to provide relevant information for day-today decision making.

From eleventh position in a 1995 Bain and Company survey of the most widely used management tools, $\mathrm{ABC}$ dropped to twenty-second place in 2001 [62], with satisfaction levels below the average for other tools and a decline in the perceived value of $\mathrm{ABC}$ [63]. However, more recent studies show renewed interest in $\mathrm{ABC}$ [64]. The following section describes the potential for $\mathrm{ABC}$ to benefit SMEs.

\section{$\mathrm{ABC}$ and SMEs: what the research says}

As described above, after a period of waning interest, $A B C$ is now backing in the headlines, with theoretical arguments continuing in its favor and evaluations in case studies and surveys around the world [65- 
70]. At the same time, growing awareness of the importance of SMEs, which as reported earlier, represent more than ninety per cent of all employment around the world, has provided the impetus for further investigation of the potential for $\mathrm{ABC}$ to help SMEs become competitive and thrive in today's competitive market environment [64], [70-82] and for the development and use of software to implement ABC, such as 3Com Technology [83] or SAS (OROS System) [84]. The literature recognizes a number of potential benefits to SMEs from ABC.

1. More accurate product costing and a meaningful financial and non-financial measure that aids in cost management and performance assessment $[64,75,85-87]$.

2. Better profitability measurements and better-informed strategic decisions about pricing, product lines and market segments $[64,65,75,70]$.

3. Accurate allocation of overhead costs and identification of areas of waste $[75,88]$.

4. Management ability to target cost reduction, manage and control budgets, measure performance, and increase efficiency $[64,70,75,86]$

5. Positive impact on business performance [89-92].

6. Facilitation of decision making, increase in productivity, and identification of activities that don't add value $[70,88]$.

7. Basis for strategic decision making and measure of continuous improvement and performance [70,93].

8. Alleviation of managers' concerns about the accuracy of cost allocations, cause-effect relationship between allocations and resources consumed, timeliness of cost/profit info, and ability to update systems $[64,70]$.

9. Challenges also remain regarding the implementation of $A B C$ in SMEs $[68,79,94-96]$.

Two theories are useful in the analysis of reasons why SMEs have experienced challenges in implementing ABC. First, Welsh et al. [97] framework of resource constraints in small businesses argues that small businesses suffer from resource poverty in three areas-time constraints creating little extra time for activities beyond day-to-day operations, financial constraints that prevent investments in and training for new systems, and expertise constraints because of the limited number of employees, who often lack specialized skills needed to support new technology systems. Second, Attewell's knowledge barrier theory [98] argues that know-how limitations and the need for organizational learning are potential barriers to innovation adoption.

For the purpose of discussion, and with reference to Welsh and White and Attewell's concepts, ABC implementation issues identified by researchers are organized below into time, financial, and expertise, and organizational learning.

Time constraints: In some cases, a significant amount of time can be involved in gathering relevant information throughout the company $[33,99]$. SME employees are often so busy with day-to-day operations that they feel that they do not have time to make the changes needed to gather data for $\mathrm{ABC}$ [81].

Financial constraints: High implementation costs can result from bringing in experts $[33,81,99-101]$ and from maintaining the system after implementation [102,103]. Fiscal problems are particularly serious for SMEs because they have fewer resources but face the same competitive challenges as larger businesses [76]. SMEs are often cash flow-strapped due to inventory in the supply chain [73] and cannot afford software tools that could assist in implementation of $\mathrm{ABC}$ $[77,78,104]$.

Expertise/know-how constraints: Data flaws can occur while gathering information from various organizational functions. SMEs experience difficulty in fitting $\mathrm{ABC}$ into existing organizational structure and IT, and identifying activities and interpreting results $[76,99]$. Some managers are simply unaware of $\mathrm{ABC}[76,77,81]$. Infrastructure for manufacturing, distribution, IT, and customer service is limited in SMEs, which also may not have the economies of scale of the data needed to operate a maximum efficiency. With limited access to retail shelf to present products to consumers [73], they often lack explicit, formalized description of business processes [60,91,92,105-108], and employees lack the necessary expertise [81].

Organizational learning constraints: Some SME managers do not understand the impact of $\mathrm{ABC}$ on the organization [33] and/or are not convinced that $\mathrm{ABC}$ can provide information to support decision making [76]. In some firms, there is a lack of sufficient data collection $[70,100,107]$, and pinpointing the specific data needed and displaying it in a manner that makes sense to employees is challenging $[33,72,73]$. The organizational learning barrier can be overcome by assistance from service bureaus and consultants, who can train employees and provide and develop the know-how needed. Employees may also resist participation in the implementation of $\mathrm{ABC}$, because they do not understand the benefits or feel that their competence is in question [98].

SMEs can avoid or minimize challenges in implementing ABC by being aware of the following "best practices:"

1. Top management's firm commitment to and support for implementing $\mathrm{ABC}$ is crucial $[72,86,88,109]$.

2. All employees affected must understand and support the process [72].

3. Training of all employees is essential $[72,86,88,110]$.

4. Incentives for employee participation must be in place [109].

5. Small teams comprised of a mix of representatives from the various departments should manage the process [111].

6. Procedures for monitoring and maintenance of theimplemented $\mathrm{ABC}$ system must put into place $[72,86,88,110,111]$

7. $\mathrm{ABC}$ system generated data can be misinterpreted and must be used with care when applied in making decisions.

8. Reports generated by ABC system do not conform to Generally Accepted Accounting Principles (GAAP) [99]; therefore, an organization using $\mathrm{ABC}$ should have two cost systems - ABC for internal use and a traditional system for preparing external reports.

9. It is possible to use software like Excel to collect and analyze data for $\mathrm{ABC}$, but companies can receive help in implementing $\mathrm{ABC}$ from a number of companies that offer consulting and software [112].

\section{A framework of variables in activity-based costing in SMEs}

Based on the above literature review, the authors have developed a framework (Figure 2) for $\mathrm{ABC}$ implementations in SMEs. In this framework, characteristics ofSMEs and ABC implementation challenges 


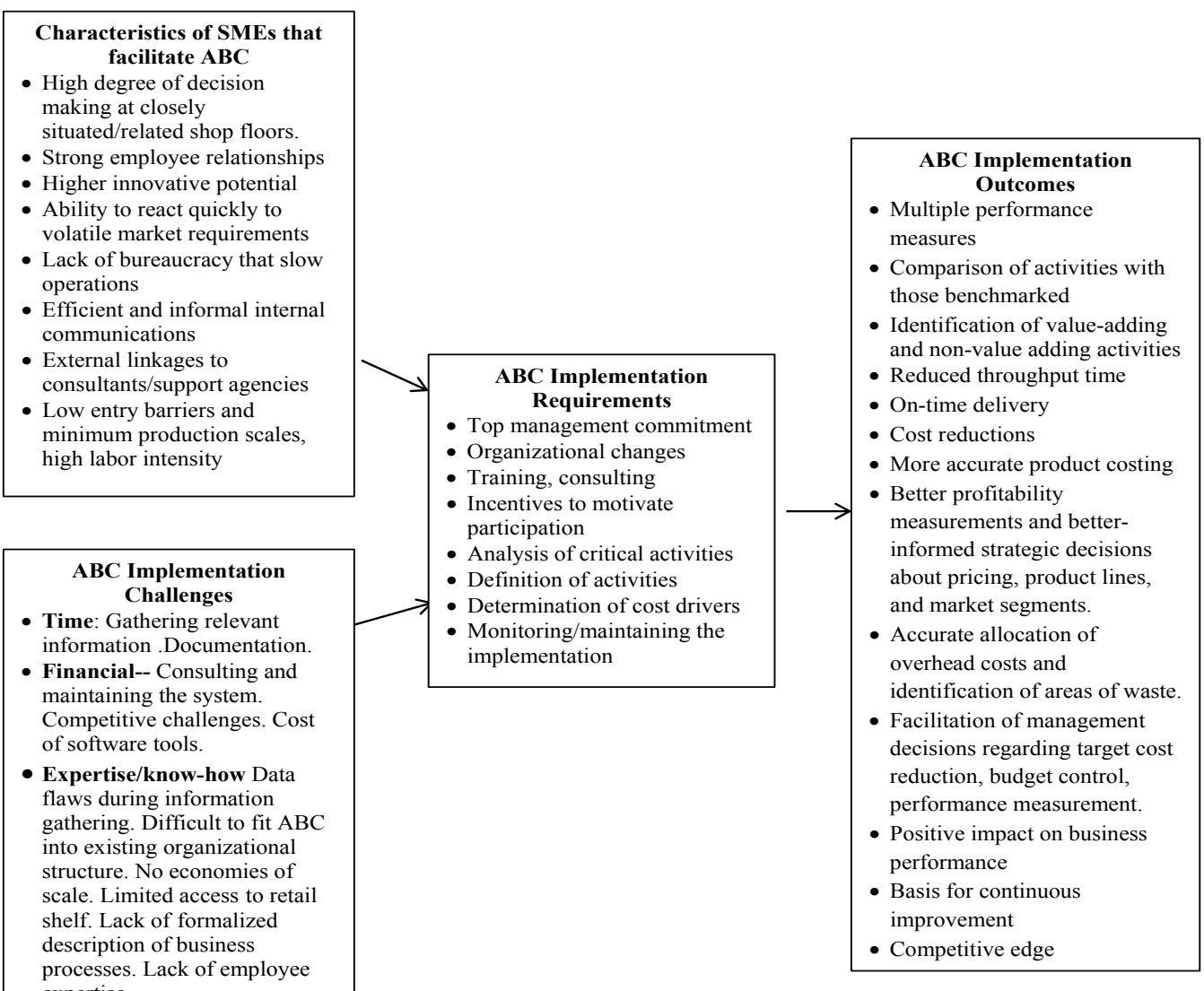
expertise.

- Organizational Learning-

Managers sometimes unaware

of impact on organization as a whole, not convinced that $\mathrm{ABC}$ will support decision making. Employees who lack skills resist implementation. Assistance from service

Figure 2: Framework for Activity-Based Costing in SMEs $[97,98,109]$.

are independent variables. $\mathrm{ABC}$ implementation requirements are implementation process variables, and $\mathrm{ABC}$ implementation outcomes are dependent variables. The research framework suggests three potential tracks of research. First, outcomes-focused research would examine the direct impact of characteristics of SMEs and ABC implementation challenges on $\mathrm{ABC}$ implementation outcomes: for example, the impact of employee resistance on the positive impact of $\mathrm{ABC}$ on business performance and continuous improvement; or, the role of strong employee relationships on the identification of valueadding and non-value adding activities.

Second, process-focused research would examine the impact of characteristics of SMEs and ABC implementation challenges on the $\mathrm{ABC}$ implementation process itself: for example, the impact of expertise on organizational changes during implementation process; or, the impact of efficient and informal internal communications on the analysis of critical activities during the implementation process.

Third, process/outcomes-based research would examine the impact of SME characteristics and $\mathrm{ABC}$ implementation challenges on the $\mathrm{ABC}$ implementation process, which, in turn, would influence the $\mathrm{ABC}$ implementation outcomes achieved: for example, the impact of the availability of external linkages to consulting on the analysis of critical activities during the implementation process and, ultimately, on the company's ability to conduct better profitability measurements and better-informed strategic decisions about pricing, product lines, and market segments.

By developing this framework to identify factors that influence what takes place during the $\mathrm{ABC}$ implementation process as well as the $\mathrm{ABC}$ implementation outcomes achieved, the authors hope to provide the basis for continued research into the successful use of $\mathrm{ABC}$ by SMEs, as well as challenges that remain.

\section{Conclusions and Future Research Directions}

As demonstrated in the above discussion, accurate costing is critical in effectively managing an enterprise's operations, and the differences in perceived profitability observed when using different costing systems are significant. Whether or not $\mathrm{ABC}$ is the best costing system for the company depends on the cost of implementation, its practicality, and the information obtained through future data collection. A standard costing system combined with a more sophisticated traditional overhead allocation system may be more practical for the company and will still yield accurate enough data where it is not significantly different from 
$\mathrm{ABC}$. The key is for management to understand the advantages and the limitations of their costing system. Basing critical decisions on faulty or incomplete information is more likely to undermine the company's current position than it is to improve it. Companies who adopt activitybased costing will find that it is not only past-focused, but can facilitate future planning by pointing out inefficiencies and waste that lower profits and impact a company's competitiveness $[66,113,114]$.

This paper has also discussed the crucial role of SMEs in free market economies worldwide, as well as the potential for activitybased costing to support SMEs' becoming and remaining competitive in the global economy. With growing world populations, the success of SMEs, which represent $95 \%$ of free-market enterprises around the world, is increasingly essential for providing the livelihood and opportunities needed. The framework presented in this paper, which identifies many of the factors, both positive and negative, that impact ABC implementations and outcomes in SMEs, provides a model for future research. The framework is not exhaustive, and companies around the world may also face the impact of additional factors. However, future studies can use the framework to compare and contrast $\mathrm{ABC}$ implementations in a variety of types of SME firms, compare $\mathrm{ABC}$ implementations in the same industry sector, study the types of consultant, educational, network, and financial support that are most effective to SMEs in implementing $A B C$, and investigate types of software that can most effectively support ABC.

\section{References}

1. Ayyagari M, Demirguc-Kunt A, Maksimovic V (2011) Small vs. young firms across the world: contribution to employment, job creation, and growth.

2. European Parliament (2006) Resolution on small and medium-sized enterprises in the developing countries (2005/2207(INI). Official Journal of the European Union.

3. Forbes.com (2012) Small businesses=big impact.

4. Sugars B (2012) Enterpreneur.com.

5. US Small Business Administration, Advocacy Office frequently asked questions.

6. Association of Chartered Certified Accountants (ACCA) (2010b) Small business: a global agenda.

7. Edinburgh Group (2012) Growing the global economy through SMEs.

8. Deijl C, de Kok J, Essen VV (2009) Is small still beautiful? Literature review of recent empirical evidence on the contribution of SMEs to employment creation. Deutsche Gesellschaft für Internationale Zusammenarbeit (GIZ) $\mathrm{GmbH}$.

9. Block JH, Thurik R, Zhou H (2009) What turns knowledge into innovative products? The role of entrepreneurship and knowledge spillovers. Erasmus Research Institute of Management Report Series, Research in Management.

10. Baumol W (2009) Small enterprises, large firms, and growth. In Anders Lundstrom, Ed., The Role of SMEs and Entrepreneurship in a Globalised Economy, Expert Report No. 34 to Sweden's Globalisation Council.

11. Association of Chartered Certified Accountants (ACCA) (2010a) Beyond the equality bill: embedding equality and diversity in SMEs.

12. World Bank Jobs and Development Overview.

13. Koshy P, Prasad VN (2007) Small and Micro Enterprises: A tool in the fight against poverty.

14. Kobe K (2012) Small business GDP: update 2002-2010. Small Business Administration, under contract no. SBAHQ-10-M-0258.

15. The Villager.com (2012) The importance of small, medium enterprises in the economy.

16. Bosma N, Levie J (2009) Global entrepreneurship monitor: 2009 global report.

17. Liedholm C, Mead D (1999) Small enterprises and economic development: the dynamic role of micro and small enterprises. London: Routledge.
18. Schmitz H (1995) Collective efficiency: Growth path for small-scale industry The Journal of Development Studies 31: 529-566.

19. O'Regan N, Ghobadian A (2002) Effective strategic planning in small and medium sized firms. Management Decision 40: 663-671.

20. Munive-Hernandez EJ, Dewhurst FW, Pritchard MC, Barber KD (2004) Modelling the strategy management process: An initial BPM approach. Business Process Management Journal 10: 691-711.

21. Abor J, Quartey P (2010) Issues in SME development in Ghana and South Africa. International Research Journal of Finance and Economics 39: 215-228.

22. Jennings D, Disney JJ (2006) Designing the strategic planning process: does psychological type matter? Management Decision 44: 598-614.

23. Dansoh A (2005) Strategic planning practice of construction firms in Ghana Construction Management and Economics 23: 163-168.

24. Economist Intelligence Unit Report (2010) Towards the recovery: challenges and opportunities facing Asia's SMEs.

25. Staubus GJ (1971) Activity costing and input-output accounting. Homewood

26. Miller JA (1995) Implementing activity based management in daily operations Hoboken, NJ: John Wiley \& Sons 236

27. Cooper R, Kaplan RS (1991) Profit priorities from activity-based costing Harvard business review 69: 130-135

28. Kaplan RS, Bruns W (1987) Accounting and management: a field study perspective. Cambridge, MA: Harvard Business School Press.

29. Johnson HT, Kaplan RS (1991) Relevance lost: the rise and fall of management accounting. Harvard Business Press.

30. Drucker PF (1999) Management challenges of the twenty-first century. New York: Harper Business.

31. Drury PF (2005) Management accounting for business decisions, third edition. New Hampshire: Thomson Learning.

32. Johnson HT (1990) Activity management: Reviewing the past and future of cost management. Journal of Cost management 3: 4-7.

33. Ness JA, Cucuzza TG (1995) Tapping the full potential of ABC. Harvard Business Review 73: 130-138.

34. Kaplan RS, Porter ME (2011) How to solve the cost crisis in health care. Harv Bus Rev 89: 46-52.

35. Gentili A (2014) Cost accounting for the radiologist. American Journal of Roentgeonology 202: 1058-1061.

36. Dwivedi R, Chakraborty S (2015) An activity-based costing model for an engineering department of an Indian university. International Journal of Accounting and Finance 5: 62-81.

37. United States Postal Service. Supplying principles and practices manual: 2.5.3 Activity based costing.

38. Carter TL, Sedaghat AM, Williams TD (1998) How ABC changed the post office. Strategic Finance 79: 28

39. Horgren CT (1995) Management accounting: this century and beyond Management Accounting Research 6: 281-286.

40. Raab C, Mayer K (2007) Menu engineering and activity-based costing-can they work together in a restaurant? International Journal of Contemporary Hospitality Management 19: 43-52.

41. Adams $M$ (1996) Activity-based costing (ABC) and the life insurance Industry. The Service Industries Journal 16: 511-526.

42. Krishnan A (2006) An application of activity-based costing in higher learning institution: a local case study. Contemporary Management Research 2: 75-90.

43. Cox KS, Downey RG, Smith LG (1999) ABC's of Higher Education. Getting Back to the Basics: An Activity-Based Costing Approach to Planning and Financial Decision Making. AIR 1999 Annual Forum Paper.

44. Cagwin D, MJ Bouwman (2002) The association between activity-based costing and improvement in financial performance. Management Accounting Research 13: 1-39.

45. Innes J, Mitchell F, Sinclair D (2000) Activity-based costing in the UK's largest 
Citation: Kocakulah MC, Foroughi A, Stott A, Manyoky L (2017) Activity-Based Costing: Helping Small and Medium-Sized Firms Achieve a Competitive Edge in the Global Marketplace. J Account Mark 6: 245. doi: 10.4172/2168-9601.1000245

companies: a comparison of 1994 and 1999 survey results. Management Accounting Research 11: 349-62.

46. Wang P, Du F, Lei D, Lin TW (2010) The choice of cost drivers in activity-based costing: Application at a Chinese oil well cementing company. International Journal of Management 27: 367.

47. Rof LM, Capusneanu S (2015) Increase the performance of companies in the energy sector by implementing the activity-based costing. International Journal of Academic Research in Accounting, Finance and Management Sciences 5 : 139-148.

48. Faraji T, Maghari A, Mirsepasi N (2015) A framework for assessing cost management system changes: the case of activity-based costing implementation at food industry. Management Science Letters 5: 413-418.

49. Binshan L, Collins J, R KS (2001) Supply chain costing: an activity-based perspective. International Journal of Physical Distribution and Logistics Management 31: 702-713.

50. Mahal I, Hossain MA (2015) Activity-based costing (ABC)-an effective tool for better management. Research Journal of Finance and Accounting 6: 66-74.

51. Gilligan BP (1990) Traditional cost accounting needs some adjustments... as easy as ABC. Industrial Engineering 34-38.

52. Hughes SB, K Paulson Gjerde (2003) Do different cost systems make a difference? Management Accounting Quarterly, Fall 22-30.

53. Wiersema WH (2007) What does this job really cost? Electrical Apparatus 48-

54. Stevenson TH, Barnes FC, Stevenson SA (1996) Activity-based costing Beyond the smoke and mirrors. Review of Business 18: 25

55. Arney D, Sorice RP (1994) Activity-based costing: a proactive management tool. Credit World 82: 17

56. Cooper R, Kaplan RS (1988) How cost accounting distorts product costs Strategic Finance 69: 20

57. Cheatham CB, Cheatham LR (1996) Redesigning cost systems: Is standard costing obsolete? Accounting Horizons 10: 23.

58. Škoda M (2009) The importance of ABC models in cost management. Annals of the University of Petrosani, Economics 9: 263-274.

59. Kaplan RS, Anderson SR (2004) Time-driven activity-based costing. Harvard Business Review 82: 131-138.

60. Hicks DT (1992) Activity-based costing for small and mid-sized businesses: an implementation guide. John Wiley \& Sons

61. Swenson D, Barney D (2001) ABC/M: Which companies have success? Journal of Corporate Accounting \& Finance 12: 35-44.

62. The Economist (2009) Easier than ABC

63. Lawson R, Hatch T (2005) Executing strategy with scorecard: best practice from around the world. Hyperion 2005 Global Solutions Conference.

64. Stratton WO, Desroches D, Lawson RA, Hatch T (2009) Activity-based costing: is it still relevant? Management Accounting Quarterly 10: 31.

65. Blocher EJ, Stout DE, Juras PE, Cokins G (2013) Cost management: a strategic emphasis (6th ed.). New York, NY: McGraw-Hill Irwin.

66. Škoda M, Sláviková G, Lajčin D (2014) The only correct calculation method in cost management: From activity based costing perspective.

67. Ríos M, Rodríguez-Vilarino ML, Ferrer J (2012) Los costos basados en actividades como herramienta de gestion en las pymes. RIGC 19.

68. Baykasoğlu A, Kaplanoğlu V (2008) Application of activity-based costing to a land transportation company: A case study. International Journal of Production Economics 116: 308-324.

69. Hernández V, Alfaro G, Zamudio CA (2006) El sistema de costes ABC (Activity Based Costing) y su aplicación en la empresa. Gestión, Calidad y Competitividad Empresarial 330-343.

70. Stefano NM, Casarotto Filho N (2013) Activity-based costing in services: literature bibliometric review. SpringerPlus 2: 80 .

71. Baxendale SJ (2001) Activity-based costing for the small business: A primer Business Horizons 44: 61-68.
72. Abdul Majid J, Sulaiman M (2008) Implementation of activity based costing in Malaysia: A case study of two companies. Asian Review of Accounting 16 : 39-55.

73. Hall O, McPeak C (2011) Are SMEs ready for ABC? Journal of Accounting and Finance 11.

74. Vanshal V, Yadav T, Ahirwar Y (2013) Options for costing system for small and medium enterprises. International Journal of Innovations in Engineering and Technology 2: 29 .

75. Dubihlela J, Rundora R (2014) Employee training, managerial commitment and the implementation of activity based costing; impact on performance of SMEs. The International Business \& Economics Research Journal (Online) 13: 27.

76. Ríos-Manríquez M, Colomina $\mathrm{Cl}$, Pastor ML (2014) Is the activity based costing system a viable instrument for small and medium enterprises? The case of Mexico. Estudios Gerenciales 330: 220-232.

77. Machado M (2012) Activity based costing knowledge: empirical study on small and medium-size enterprises. Revista Contemporanea de Contabilidad 9: 167-

78. Shil NC, Pramanik AK (2012) Application of activity based costing in manufacturing companies in bangladesh: a survey based study. The USV Annals of Economics and Public Administration, Stefan Mare University of Suceava, Romania, Faculty of Economics and Public Administration 12: 170 182

79. Roztocki N, Schultz SM (2003) Adoption and implementation of activity-based costing: a web-based survey. InlIE Annual Conference. Proceedings $2003 \mathrm{Jan}$ 1 (p. 1). Institute of Industrial and Systems Engineers (IISE).

80. Harash E, Al-Timimi S, Radhi AH (2014) Influence of Accounting Information Systems (AIS) on Performance of Small and Medium Enterprises (SMEs) in Iraq. Journal of Business \& Management 3: 48-57.

81. Huynh T, G Gong G, Ngo H (2013) Integration of activity-based budgeting and activity-based management. International Journal of Economics, Finance and Management Sciences 1: 181-187.

82. Özyürek H, Ulutürk $Y$ (2015) Application of activity based costing methods given strategic decisions in private education. European Journal of Accounting Auditing and Fianance Research 3: 1-4.

83. Vázquez $R$ (2004) Pymes a la vanguardia tecnológica en sistemas de información. ITESM

84. Januszewski A (2008) Activity-based costing system for a small manufacturing company: A case study. Encyclopedia of Decision Making and Decision Support Technologies 30:1-9.

85. Innes J, Mitchell F (1990) Activity-Based Costing: A Review with Case Studies. Charted Institute of Management Accounts, UK.

86. Gunasekaran A (1999) A framework for the design and audit of an activitybased costing system. Managerial Auditing Journal 14: 118-127.

87. Berts K, Kock S (1995) Implementation considerations for activity based costing in service firms. Management Decisions 33: 57-63.

88. Gunasekaran A, Sarhadi M (1998) Implementation of activity-based costing in manufacturing. International Journal of Production Economics 56: 231-242.

89. Wilson JW, Eilertsen S (2010) How did strategic planning help during the economic crisis? Strategy \& Leadership 3: 5-14.

90. Efendioglu AM, Karabulut T (2010) Impact of strategic planning on financia performance of companies in Turkey. International Journal of Business and Management 5: 3.

91. Hicks DT (1999) Yes, ABC is for small businesses, too. Journal of Accountancy $41-44$

92. Hicks DT (2002) Activity-based costing: making it work for small and mid-sized companies, second ed. New York: John Wiley and Sons 25

93. Lombardo C (2015) Activity based costing advantage and disadvantages.

94. Banker RD, Bardhan IR, Chen TY (2008) The role of manufacturing practices in mediating the impact of activity-based costing on plant performance. Accounting, organizations and society $33: 1-9$

95. Garbey N (2003) Antecedentes, ventajas y limitaciones del costeo po actividades, Gestiopolis 4: 1-10. 
Citation: Kocakulah MC, Foroughi A, Stott A, Manyoky L (2017) Activity-Based Costing: Helping Small and Medium-Sized Firms Achieve a Competitive Edge in the Global Marketplace. J Account Mark 6: 245. doi: 10.4172/2168-9601.1000245

96. Stapleton D, Pati S, Beach E, Julmanichoti P (2004) Activity-based costing for logistics and marketing. Business Process Management Journal 10: 584-597.

97. Welsh JA, White JF, Dowell P (1982) A Small Business is not a Little Big Business Harvard Business Review, Vol. 59, No. 4, July/August, 1981, pp. 18 (9 pages. International Small Business Journal 1: 95.

98. Attewell $P$ (1992) Technology diffusion and organizational learning: the case of business computing. Organization Science 3: 1-19.

99. Rasiah D (2011) Why activity based costing (ABC) is still tagging behind the traditional costing in Malaysia? Journal of Applied Finance and Banking 1: 83-106.

100.Khazanchi D (2005) Information technology (IT) appropriateness: the contingency theory of "fit" and it implementation in small and medium enterprises. Journal of Computer Information Systems 45: 88.

101.Drury C (2008) Management and cost accounting, cengage learning EMEA.

102. Raiborn CA, Kinney MR (2009) Cost accounting: foundations and evolutions Mason: South Western/Cengage Learning.

103. Carnes $P$, Turrola A (2010) The diffusion of management accounting systems in manufacturing companies: An empirical analysis of Italian firms. Studies in Managerial and Financial Accounting 20: 457

104.Bharara A, Lee CY (1996) Implementation of an activity-based costing system in a small manufacturing company. International Journal of Production Research 34: 1109-1130.

105. Cannavacciuolo L, landoli L, Ponsiglione C, Zollo G (2012) An analytica framework based on AHP and activity-based costing to assess the value of competencies in production processes. International Journal of Production Research 50: 4877-88.

106. Macpherson A, Jones O, Zhang M (2005) Virtual reality and innovation networks: opportunity exploitation in dynamic SMEs. International Journal of Technology Management 30: 49-66.

107. Roztocki N, Porter JD, Thomas RM, Needy KL (2004) A procedure for smooth implementation of activity-based costing in small companies. Engineering Management Journal 16: 19-27.

108. Needy KL, Bidanda B, Gulsen M (2000) A model to develop, assess, and validate an activity-based costing system for small manufacturers. Engineering Management Journal 12: 31-38.

109. Gunasekaran A, Marri HB, Grieve RJ (1999) Justification and implementation of activity based costing in small and medium-sized enterprises. Logistics Information Management 12: 386-394.

110. Ehlers T, Lazenby R (2007) Strategic management: southern African concepts and cases, second ed. Pretoria: Van Schaik.

111. Hughes A (2005) ABC/ABM-activity-based costing and activity-based management: a profitability model for smes manufacturing clothing and textiles in the UK. Journal of Fashion Marketing and Management: An International Journal 9: 8-19.

112. Bhatti AT (2012) Activity-based-costing-system.

113. Roztocki N (2001) Activity-based costing for e-business. Proceedings of PICMET'01, Vol. 2, Portland, Oregon.

114. Jeyaraj SS (2015) Activity based costing vs. volume based costing: relevance and applicability. Journal of International Management 4: 39-46. 